\title{
Correction: Jindal, P.C. A New Method for Evaluating the Indentation Toughness of Hardmetals. Crystals 2018, 8, 197
}

\section{Prem C. Jindal}

Independent Scholar, 615 Westchester Drive, Greensburg, PA 15601, USA; jindalprem@yahoo.com

Received: 11 August 2020; Accepted: 17 November 2020; Published: 21 December 2020

The authors wish to make the following correction to the paper [1]. In page 5, we need to modify Tables 1 and 2 into the following:

Table 1. Data from Exner et al. [10] on Co Vol \%; Vickers hardness and toughness.

\begin{tabular}{ccc}
\hline SP\# (Co Vol \%) & Vickers Hardness & Km \\
\hline 5.1 & 1705 & 27.2 \\
\hline 10.1 & 1603 & 30.8 \\
\hline 14.8 & 1390 & 38.1 \\
\hline
\end{tabular}

Table 2. Data from Seikh et al. [9] on Co Vol \%; Vickers hardness and toughness.

\begin{tabular}{ccc}
\hline SP\# (Co Vol \%) & Vickers Hardness & Km \\
\hline 4.2 & 1782 & 30.5 \\
\hline 7.5 & 1748 & 29.8 \\
\hline 10 & 1591 & 39.0 \\
\hline 15.6 & 1483 & 39.9 \\
\hline
\end{tabular}

(Reason) The $\mathrm{Km}$ and Wm values as given in Tables 1 and 2 were incorrect because the method proposed in the paper cannot be used for carbide materials vacuum annealed from coating temperatures typical of MTCVD/CVD coating temperatures when there is no change of room temperature Vickers Hardness after cooling from coating temperatures. Therefore, Indentation toughness of as sintered carbide materials (Reference 9) cannot be compared with indentation toughness of vacuum annealed carbide materials (Reference 10).

Shetty and colleagues (Reference 5) proposed another method as given in Equation (3) of the paper [1]. Indentation Toughness $(\mathrm{Km})$ were calculated for both the as sintered carbide materials and vacuum annealed carbide materials as given in the corrected Tables 1 and 2. It is to be noted that indentation toughness is inversely proportional to its Vickers Hardness for both sets of carbide materials. It is also very clear that as sintered carbide materials (Reference 9) have higher indentation toughness than the vacuum annealed carbide carbide materials (Reference 10) at a given level of Vickers Hardness.

These changes have no material impact on the discussion and conclusions of the paper. The authors would like to apologize for any inconvenience caused to the readers by these changes. 


\section{Reference}

1. Jindal, P.C. A new method for evaluating the indentation toughness of hardmetals. Crystals 2018, 8, 197. [CrossRef]

Publisher's Note: MDPI stays neutral with regard to jurisdictional claims in published maps and institutional affiliations.

(C) 2020 by the author. Licensee MDPI, Basel, Switzerland. This article is an open access article distributed under the terms and conditions of the Creative Commons Attribution (CC BY) license (http://creativecommons.org/licenses/by/4.0/). 